\title{
PENGARUH RANCANGAN BARISAN DAN PERIODE PANGKAS TERHADAP BIOMASA DAN HASIL UNSUR HARA TITONIA (Tithonia diversifolia) PADA ULTISOL
}

\author{
Asmar, Oktanis Emalinda, Dicky Hadi Vendra
}

\begin{abstract}
A field research about cultivating tithonia (Tithonia divesifolia) was aimed to determine the best row design and trimming period to produce high biomass and nutrient content of tithonia in Ultisol. The research was conducted in Andalas University Experiment Station and Laboratory of Research Center for Utilization of Nuclear Science and Technology (P3IN) Universitas Andalas Limau Manis Padang. The research consisted of 2 factors, row design for tithonia cultivation at farming site $(\mathrm{R})(\mathrm{R} 1=$ alley fence, $1 \mathrm{~m}$ width times $5 \mathrm{~m}$ distance; $\mathrm{R} 2=1 \mathrm{~m}$ width as a fence for farming site $10 \mathrm{~m} \times 10 \mathrm{~m}$ area) as the main plot and trim period (U) (U1=trimming every 2 month, U2=trimming every 4 months), at 3 blocks The results showed that both row designs gave the same performance in terms of producing biomass and plant nutrients $(\mathrm{N}, \mathrm{P}, \mathrm{K}, \mathrm{Ca}, \mathrm{Mg})$. The best trimming period was found under U1. Tithonia cultivation as R1 combined with trimming period (U1) yielded approximately 2.2 ton dry matter/ha, 62.82 $\mathrm{kg} \mathrm{N} / \mathrm{ha} ; 17.67 \mathrm{~kg} \mathrm{P} / \mathrm{ha} ; 81.06 \mathrm{~kg} \mathrm{~K} / \mathrm{ha} 13.35 \mathrm{~kg} \mathrm{Ca} / \mathrm{ha}$ and $5.47 \mathrm{~kg} \mathrm{Mg} / \mathrm{ha}$. Both row designs with trimming period every 2 months could be recommended to cultivate tithonia in Ultisol.
\end{abstract}

\section{Key Words: Tithonia diversifolia cultivation, trim period, Ultisol}

\section{PENDAHULUAN}

Tanah merupakan media tumbuh tanaman yang utama dan perlu mendapatkan perhatian, terutama mengenai kesuburannya karena akan mempengaruhi tingkat produktivitasnya. Menurut Soepraptohardjo (1978), di Indonesia umumnya tanah yang dijadikan persawahan dan usaha pertanian lahan kering berasal dari tanah Alluvial (Entisol), Latosol (Oxisol), Podzolik (Ultisol) dan Andosol. Diantara tanah tersebut Ultisol mempunyai penyebaran yang paling luas, yaitu sekitar 45,8 juta hektar yang tersebar di Sumatera, Kalimantan, Sulawesi, dan Irian Jaya (Subagyo, Suharta, dan Siswanto, 2000). Menurut Hardjowigeno (2003), Ultisol memiliki masalah tingkat kesuburan yang rendah seperti reaksi yang masam, miskin bahan organik serta kejenuhan $\mathrm{Al}$ yang tinggi. Untuk mengatasi masalah tersebut diperlukan penambahan kapur untuk mengurangi kemasaman tanah dan penggunaan pupuk buatan yang banyak. Tindakan ini diharapkan dapat memperbaiki sifat fisik, kimia, dan biologi tanah agar pertumbuhan tanaman optimal. Penambahan pupuk buatan yang terus menerus membutuhkan biaya yang besar karena harga pupuk buatan yang cenderung terus naik dari tahun ke tahun.

Mulai tahun 1996, harga pupuk Urea dan $\mathrm{KCl}$ meningkat tajam. Harga pupuk Urea/kg berturut-turut dari tahun 1996 sampai 2002 adalah Rp 477,-/kg (1996), Rp 654,-/kg (1997), Rp 1100,-/kg (1998), Rp 1100,-/kg (1999), Rp 1150,-/kg (2000), Rp $1150,-/ \mathrm{kg}$ (2001), Rp 1150,-/kg (2002). Harga pupuk $\mathrm{KCl} / \mathrm{kg}$ pada tahun 1996 sebanyak Rp 550,-/kg, pada tahun 2001 menjadi $\mathrm{Rp} 1575,-/ \mathrm{kg}$ dan meningkat lagi menjadi Rp 1610,-/kg pada tahun 2002 (Harian Kompas,1996 ; Singgalang, 1996 ; BPS, 2000 ; Toko Saprotan ; Hasil wawancara dengan PT PUSRI, 2002, cit Gusmini, 2003). Yumna (2006), menyatakan bahwa pada tahun 2003 harga Urea/kg sudah mencapai Rp1500,-/kg. Bibowo (2005), melaporkan ditingkat pengecer di kota Padang pada tahun 2004 harga Urea Rp 1500,-/kg, sedangkan harga KCl Rp 2400,$/ \mathrm{kg}$ Pada tahun 2006 ditingkat pengecer di kota Padang harga Urea Rp 2200,-/kg dan $\mathrm{KCl}$ Rp 3200,-/kg.

Melihat banyaknya tantangan yang dihadapi, maka berbagai metoda untuk mengurangi pemakaian pupuk buatan tanpa mengurangi produksi perlu dicari, misalnya 
dengan penggunaan pupuk hijau. Pupuk hijau merupakan tanaman atau bagian tanaman yang masih muda yang dibenamkan ke dalam tanah dengan tujuan dapat meningkatkan ketersediaan bahan organik dan unsur hara bagi pertumbuhan dan perkembangan tanaman yang akan diusahakan (Sarief, 1986).

Tanaman pupuk hijau yang umum digunakan adalah dari famili leguminoceae atau legume. Akan tetapi Hakim, et al (1994), menyatakan bahwa tanaman legum tidak selalu berhasil tumbuh baik pada tanah - tanah miskin unsur hara dengan kesuburan tanah yang rendah sehingga tidak menghasilkan pertumbuhan yang baik dan produk biomass yang tinggi. Berbeda dengan tanaman titonia (Tithonia diversifolia) atau bunga matahari Mexico dapat tumbuh disembarang tempat dan jenis tanah (Hakim, 2001)

Titonia merupakan salah satu tanaman semak atau gulma yang berpotensi sebagai pupuk hijau, karena mengandung $\mathrm{N}$ dan $\mathrm{K}$ yang cukup tinggi Titonia berasal dari Mexico dan sekarang telah tersebar luas di daerah tropik basah dan sub humid di Amerika Tengah dan Selatan serta Afrika dan Asia (Sonke, 1997 cit Hakim, 2001) Daun tithonia kering mengandung hara yang tinggi yaitu sekitar 3,5\% N, 0,37\% P, dan $4,1 \% \mathrm{~K}$ Sebagai tanaman pagar titonia dapat menghasilkan $1 \mathrm{~kg}$ bahan kering/meter/ tahun. Biomasa titonia mudah diuraikan sehingga efektif untuk sumber $\mathrm{N}$ dan $\mathrm{K}$ (Sonke, 1997 cit Hakim 2001). Di Indonesia titonia belum populer dimanfaatkan dan belum ditemukan literatur yang memuat informasi lengkap tentang tumbuhan ini. Di Sumatera Barat titonia tumbuh sebagai semak di pinggiran jalan dan belum dimanfaatkan sebagai pupuk hijau (Hakim, 2002).

Dari hasil penelitian Hakim, et al. (2003) diketahui bahwa titonia dapat mensubsitusi $25-50 \% \mathrm{~N}$, K pupuk buatan untuk tanaman cabai, tomat, dan jahe. Bahkan hasil penelitian Fidorova (2003) menyatakan bahwa pertumbuhan jagung yang diberi $100 \% \mathrm{~N}$ titonia tumbuh lebih baik dari pada yang diberi $100 \% \mathrm{~N}$ dari Urea.

Hakim (2001), menyatakan bahwa jika titonia dibudidayakan sebagai pagar keliling kebun pada lahan satu hektar dengan lebar satu meter, maka akan dihasilkan sekitar $3680 \mathrm{~kg}$ bahan segar, atau $700 \mathrm{~kg}$ bahan kering/ha/tahun. Jika titonia dijadikan pagar lorong dengan jarak pagar $10 \mathrm{~m}$, maka dalam 1 ha akan terdapat 11 baris $(1100 \mathrm{~m})$,maka akan diperoleh sekitar 10 ton titonia segar, atau sekitar 2 ton titonia kering per tahun. Bila $1 / 3$ luas lahan $\left(3300 \mathrm{~m}^{2}\right)$ ditanami titonia yang akan digunakan untuk memupuk 2/3 lahan usaha tani, maka akan dihasilkan sekitar 30 ton bobot basah atau sekitar 6 ton bahan kering. Dari hasil penelitian budidaya tithonia dalam pot, Zamora (2004) melaporkan bahwa bahan perbanyakan titonia dengan stek batang menghasilkan bobot segar tertinggi, yaitu sebanyak 159,8 gpot ${ }^{-1}$ dan bobot kering sebanyak 32,76 gpot $^{-1}$. Ia juga menemukan bahwa periode pangkas empat bulan adalah terbaik dan menghasilkan bobot segar sebanyak 169,57 gpot $^{-1}$ dan bobot kering sebanyak 37,04 gpot $^{-1}$. Akan tetapi percobaan ini masih dalam bentuk percobaan pot, sehingga perlu diuji dalam bentuk percobaan lapangan. Hasil penelitian Deswita (2004) menyatakan bahwa jarak tanam titonia yang terbaik adalah $50 \mathrm{~cm} \mathrm{x}$ $50 \mathrm{~cm}$ dengan input pupuk pada awal tanam sebanyak $10 \mathrm{~g} \mathrm{~N}+1 \mathrm{~g} \mathrm{P}+10 \mathrm{~g} \mathrm{~K}+0,5 \mathrm{~g}$ $\mathrm{Mg}+2 \mathrm{~kg}$ pukan $/ \mathrm{m}^{2}$.

Berdasarkan hasil - hasil penelitian tersebut dapat disimpulkan bahwa biasanya titonia dapat diperbanyak dengan stek batang, jarak tanam $50 \mathrm{~cm} \times 50 \mathrm{~cm}$ dan diberi pupuk. Akan tetapi seperti apa patron (rancangan barisan) penanamannya di lapangan, sehingga mudah diangkut ke lokasi usaha tani, dan menghasilkan biomasa yang tinggi, masih perlu dikaji. Apakah titonia akan ditanam sebagai pagar kebun yang membatasi luas lahan setiap $10 \mathrm{~m} \times 10$ $\mathrm{m}$, atau ditanam sebagai pagar lorong dengan jarak lorong 5 meter adalah pertanyaan yang perlu dijawab melalui penelitian. Walaupun periode pangkas yang tepat menurut Zamora (2004) adalah tiap 4 bulan, tetapi apakah hal yang sama juga akan ditemukan di lapangan. Oleh karena itu periode pangkas titonia pada budidaya di lapangan masih perlu diteliti.

Berdasarkan masalah dan informasi yang telah dikemukakan di atas, maka 
penulis telah melakukan penelitian dengan judul " Pengaruh Rancangan Barisan dan Periode Pangkas Terhadap Biomasa dan Hasil Unsur Hara Titonia (Tithonia diversifolia) Pada Ultisol “. Tujuan penelitian ini adalah untuk mengetahui rancangan barisan dan periode pangkas yang tepat untuk budidaya titonia di lapangan, sehingga diperoleh biomassa dan kandungan unsur hara tithonia yang tinggi pada Ultisol. Hasil penelitian ini diharapkan akan bermanfaat dalam menyusun pedoman teknik budidaya titonia di lapangan, sehingga diperoleh biomasa dan kandungan unsur hara yang tinggi pada Ultisol.

\section{BAHAN DAN METODA}

Penelitian ini telah dilaksanakan di Kebun Percobaan Fakultas Peternakan Universitas Andalas Padang dari bulan Oktober 2004 sampai Maret 2005. Analisis tanah dan tanaman telah dilaksanakan dilaboratorium P3IN Universitas Andalas Padang. Bahan yang digunakan dalam penelitian ini adalah bahan perbanyakan titonia berupa stek batang yang diambil dari Sicincin. Tanah yang digunakan adalah Ultisol yang berada di Kebun Percobaan Fakultas Peternakan Universitas Andalas Padang. Pupuk kandang, pupuk Urea, $\mathrm{KCl}$, TSP dan Kiserit digunakan sebagai pupuk dasar.

Rancangan percobaan yang digunakan dalam penelitian ini adalah faktorial $2 \times 2$ yang ditempatkan secara petak terbagi dengan tiga kelompok (K). Petak utama adalah rancangan barisan tithonia $(\mathrm{R})$ yang terdiri atas dua taraf yaitu; $\mathrm{R} 1$ = baris tanam pagar lorong lebar 1 meter jarak 5 meter, R2 = baris tanam lebar 1 meter pagar kebun luas lahan $10 \mathrm{~m}$ x $10 \mathrm{~m}$. Sedangkan anak petak yaitu umur pangkas (U) yang terdiri atas 2 taraf yaitu $\mathrm{U} 1$ = setiap 2 bulan, $\mathrm{U} 2$ = setiap 4 bulan.

Tanah untuk pembibitan titonia diambil dari Kebun Percobaan Fakultas Peternakan Limau Manis secara bulk komposit dengan kedalaman $0-20 \mathrm{~cm}$ (lapisan olah). Tanah ini dikering-anginkan kemudian dilakukan pemecahan bongkahan tanah sehingga menjadi lebih halus. Setelah pemecahan bongkahan kemudian tanah dicampur dengan pupuk kandang dengan perbandingan $3: 1$ dan dimasukkan ke dalam polybag ukuran $1 \mathrm{~kg}$. Kemudian polybag yang telah berisi campuran tanah dan pupuk kandang tersebut disiram sampai kapasitas lapang dan diinkubasikan selama seminggu.

Bahan perbanyakan titonia yang telah digunakan diambil dari Sicincin Batang titonia dipotong-potong dari pangkal batang sampai ujung daun yang mati, kurang lebih $30 \mathrm{~cm}$ dari pangkal batang. Batang titonia yang diambil tidak terlalu tua dan juga tidak terlalu muda, tujuannya agar tithonia yang akan dijadikan stek tidak terlalu mengayu karena sudah tua dan batang tithonia tidak terlalu lunak karena masih muda. Selanjutnya dipotong-potong sekitar $25 \mathrm{~cm}$ atau 4 mata tunas. Berdasarkan luas lahan yang akan ditanami seluruhnya $560 \mathrm{~m}^{2}$ dan tiap $\mathrm{m}^{2}$ terdapat 4 tanaman, maka untuk percobaan ini dibutuhkan sebanyak 2240 stek tithonia. Batang titonia yang telah dipotong-potong sepanjang $25 \mathrm{~cm}$ tersebut, bagian pangkalnya dilumuri dengan Rootone $\mathrm{F}$ untuk meransang pertumbuhan akarnya, kemudian ditusukan ke dalam tanah sekitar $10 \mathrm{~cm}$ terbenam. Stek yang tidak tumbuh dilakukan penyisipan.

Lahan yang telah digunakan di lapangan bertempat di Kebun Percobaan Fakultas Peternakan Universitas Andalas Padang. Lahan disiapkan sebagai perlakuan rancangan barisan. Jarak tanam yang digunakan untuk tithonia dalam penelitian ini, yaitu jarak tanam $50 \mathrm{~cm} \times 50 \mathrm{~cm}$ dan input pupuk sebanyak $10 \mathrm{~g} \mathrm{~N}+1 \mathrm{~g} \mathrm{P}+10 \mathrm{~g} \mathrm{~K}+1$ $\mathrm{g} \mathrm{Mg}+1 \mathrm{~kg}$ pukand $\mathrm{m}^{2}$. Jumlah pupuk tersebut sama dengan 22,22 g Urea, 2,5g TSP, 10 g KCL, 6,25 g Kiserit. Oleh karena setiap $1 \mathrm{~m} 2$ terdapat 4 tanaman, maka setiap lubang tanam mendapat pupuk sebanyak 5,55 g Urea, 0,625 g TSP, 2,5 g KCL, dan 1,56 g Kiserit. Jarak tanam dan takaran pupuk didasarkan hasil penelitian Deswita (2004).

Pemindahan bibit dilakukan setelah bibit berumur 30 hari atau mempunyai daun sekitar 4-5 helai, dengan cara sebagai berikut: Polybag dibuka dengan silet dan media tempat melekatnya akar harus dipertahankan jangan sampai pecah. Kemudian bibit ditanam kedalam lobang tanam yang telah dipersiapkan dan diberi 
pupuk di lapangan. Pembenaman dilakukan sebatas leher akar, kemudian tanah sekitar bibit dipadatkan.

Panen atau pemangkasan dilakukan sesuai dengan periode pangkasnya yaitu periode pangkas pertama (U1) dipangkas setelah tumbuh selama dua bulan, sedangkan periode pangkas kedua (U2) dipangkas setelah berumur empat bulan. Pemangkasan dilakukan dengan cara memotong batang tithonia tersebut diatas daun yang telah mati. Hasil pangkasan tersebut dinamakan hasil biomasa segar dan dikeringkan sebagai hasil biomasa kering. Selanjutnya dianalisis kadar haranya sebagai dasar untuk menghitung hasil hara titonia.

Analisis tanah dilakukan setelah diberi perlakuan meliputi analisa nilai $\mathrm{pH}$ tanah dengan $\mathrm{H}_{2} \mathrm{O}(1: 1)$ dan $\mathrm{KCl}(1: 1)$ diukur dengan $\mathrm{pH}$ meter, jumlah $\mathrm{Al}-\mathrm{dd}$ dengan metoda Volumetri yang diekstrak dengan $1 \mathrm{~N} \mathrm{KCl}$. Kandungan $\mathrm{N}$ total diukur dengan metoda Kjehdahl, kadar $\mathrm{K}$ - dd dengan amonium asetat $\mathrm{pH} 7$ diukur dengan Flame photometer serta kadar P tersedia ditentukan dengan metoda Bray II C-organik dengan metoda Walkley dan Black. Pengambilan sampel tanah dilakukan setelah dilakukan pemangkasan.

Parameter tanaman yang telah diamati berupa: (1) Jumlah cabang/rumpun/periode pangkas, (2) Jumlah daun/rumpun/periode pangkas, (3) Bobot segar dan bobot kering/periode pangkas, (4) Kadar dan hasil $\mathrm{N}, \mathrm{P}, \mathrm{K}, \mathrm{Ca}$ dan $\mathrm{Mg}$.

\section{HASIL DAN PEMBAHASAN}

\section{Sifat Kimia Tanah}

Hasil analisis berbagai ciri kimia tanah setelah pemangkasan I dan II di sajikan dalam (Tabel 1). Pada Tabel 1 dapat dilihat bahwa pada tanah yang periode pangkas (U) pada masing-masing rancangan barisan(R) berdasarkan kriteria, dapat dinyatakan bahwa kandungan N-total berada pada kisaran sedang, P-tersedia dari rendah sampai sedang, K-dd rendah sampai sedang dan C-organik rendah sampai sedang. Dari Tabel 1 dapat dilihat bahwa $\mathrm{pH}$ tanah berada pada kisaran sangat masam sampai masam.

Tanah ini tergolong pada Ultisol atau tanah yang telah berkembang lanjut. Nilai $\mathrm{pH}$ tanah pada penelitian ini yang berkisar dari sangat masam sampai masam disebabkan terjadinya hidrolisis $\mathrm{Al}$ yang menghasilkan ion $\mathrm{H}$. Di samping itu, ion $\mathrm{H}$ terjerap juga merupakan sumber ion $\mathrm{H}$ dalam tanah masam. Hakim et al (1986) menyatakan ion $\mathrm{H}$ yang terjerap pada koloid humus masam dan pada muatan permanent koloid liat dapat dipertukarkan, sehingga berada dalam keadaan seimbang dalam larutan tanah yang menyebabkan $\mathrm{pH}$ larutan tanah menjadi rendah.

Pada Tablel 1 dapat diketahui kandungan N-total tanah berada pada kisaran sedang. Perlakuan rancangan baris tanam dan periode pangkas memberi pengaruh pada N-total tanah, perlakuan pagar lorong jarak $5 \mathrm{~m}$ meningkatkan kandungan $\mathrm{N}$ sebesar $0,093 \%$ dari $0,280 \%$ pada periode pangkas 2 bulan (U1) menjadi $0,373 \%$ pada periode pangkas 4 bulan (U2). Peningkatan ini diduga karena adanya residu pupuk $\mathrm{N}$ dari penelitian terdahulu dan juga oleh sumbangan unsur hara dari pupuk kandang yang telah terdekomposisi oleh mikroorganisme serta berasal dari guguran daun titonia. Namun demikian, pada perlakuan pagar kebun $10 \mathrm{~m}$ x $10 \mathrm{~m}$ terjadi penurunan kandungan $\mathrm{N}$ sebesar $0.101 \%$ dari $0.336 \%$ pada periode pangkas 2 bulan (U1) menjadi $0.235 \%$ pada periode pangkas 4 bulan (U2). Hal ini diduga karena adanya ketidak-seimbangan hara dalam tanah dan kehilangan akibat pencucian. Syarief (1986) menyampaikan bahwa nitrat sangat mudah larut dalam air dan bila tidak dipergunakan oleh jasad renik atau tanaman tingkat tinggi akan hilang akibat tercuci.

Perbedaan periode pangkas berpengaruh pada $\mathrm{P}$ tersedia tanah pada (Tablel 1) memperlihatkan adanya penurunan $\mathrm{P}$ tersedia tanah, baik pada pagar lorong jarak $5 \mathrm{~m}$ maupun pada pagar kebun 
Tablel 1. Analisis berbagai ciri kimia tanah setelah pemangkasan 2 bulan dan 4 bulan

\begin{tabular}{|c|c|c|c|c|c|c|c|}
\hline Perlakuan & $\begin{array}{l}\mathrm{pH} \\
\mathrm{H} 2 \mathrm{O}\end{array}$ & $\mathrm{pH} \mathrm{KCl}$ & $\begin{array}{c}\text { C-organik } \\
(\%)\end{array}$ & $\begin{array}{c}\text { N-total } \\
(\%)\end{array}$ & $\begin{array}{l}\text { P-tersedia } \\
(\mathrm{ppm})\end{array}$ & $\begin{array}{c}\mathrm{K}-\mathrm{dd} \\
(\mathrm{me} / 100 \\
\mathrm{g})\end{array}$ & $\begin{array}{c}\text { Al-dd } \\
(\mathrm{me} / 100 \\
\mathrm{g})\end{array}$ \\
\hline R1U1 & $4,50 \mathrm{~m}$ & 4,01 & $2,17 \mathrm{sd}$ & $0,28 \mathrm{sd}$ & $14,17 \mathrm{sd}$ & $0,39 \mathrm{r}$ & 3 \\
\hline R1U2 & $4,51 \mathrm{~m}$ & 3,90 & $1,79 \mathrm{r}$ & $0,37 \mathrm{sd}$ & $11,97 \mathrm{r}$ & $0,49 \mathrm{sd}$ & 2 \\
\hline R2U1 & $4,34 \mathrm{sm}$ & 4,00 & $2,13 \mathrm{r}$ & $0,34 \mathrm{sd}$ & $8,56 \mathrm{r}$ & $0,27 \mathrm{r}$ & 1 \\
\hline R2U2 & $4,31 \mathrm{sm}$ & 3,89 & $2,24 \mathrm{r}$ & $0,24 \mathrm{sd}$ & $7,22 \mathrm{r}$ & $0,26 \mathrm{r}$ & 2,75 \\
\hline Keterangan & & $\begin{array}{l}\mathrm{sm} \\
\mathrm{m} \\
\mathrm{sd} \\
\mathrm{r} \\
\mathrm{R} 1 \\
\mathrm{R} 2\end{array}$ & $\begin{array}{l}\text { : sangat masar } \\
\text { masam } \\
\text { : sedang } \\
\text { : rendah } \\
\text { pagar lorong } \\
\text { pagar kebun }\end{array}$ & $\begin{array}{l}\text { ebar } 1 \mathrm{~m} \\
\text { ebar } 1 \mathrm{~m}\end{array}$ & $\begin{array}{l}\text { rak } 5 \mathrm{~m} \mathrm{pa} \\
\text { etak } 10 \mathrm{~m}\end{array}$ & $\begin{array}{l}\text { luas lahan } \\
10 \mathrm{~m} \text { pada }\end{array}$ & $\begin{array}{l}\mathrm{m} \times 20 \mathrm{~m} \\
\text { as lahan } 20\end{array}$ \\
\hline $\mathrm{m} \times 20 \mathrm{~m}$ & & $\begin{array}{l}\mathrm{U} 1 \\
\mathrm{U} 2\end{array}$ & $\begin{array}{l}\text { : periode pang } \\
\text { periode pang }\end{array}$ & 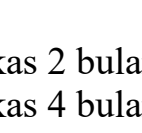 & & & \\
\hline
\end{tabular}

$10 \mathrm{~m} \times 10 \mathrm{~m}$. Penurunan $\mathrm{P}$ tersedia tanah pada pagar lorong jarak $5 \mathrm{~m}$ sebesar 2 butan (U1) menja 11,973\% pada . periode pangkas 4 bulan. Pels pan ini diduga akibat tidak dilakukannya pemupukan lanjutan, dimana hanya dilakukan pada awal penanaman dan has tithonia tidak dikembalikan lagi ke area tanam tithonia namun digunakan untuk perlakuan lainnya. Selain itu $\mathrm{pH}$ tanah jug mempengaruhi ketersediaan $\mathrm{P}$ didalan anah, pada penelitian ini $\mathrm{pH}$ tanah berad pada kisaran sangat masam sampai masam. Menurut Hakim et al (1986) ketersediaan $\mathrm{P}$ dipengaruhi sangat nyata oleh $\mathrm{pH}$, pada $\mathrm{pH}$ masam ion $\mathrm{P}$ akan mudah bersenyawa dengan $\mathrm{Al}, \mathrm{Fe}$, atau $\mathrm{Mn}$ yang akan membuat $\mathrm{P}$ tidak tersedia bagi tanaman. Hasil analisis K-dd menunjukkan adanya kecenderungan penuruna kandungan K-dd tanah seiring dengan perpanjangan periode pangkas. Kehilon ini diduga disebabkan oleh terangkut Menurut Hakim et al (1986) kehilangan kalium akibat al (1986) kehilangan kalium akibat terangku bagian tanaman diangkut dari lapangan.
Pada penelitian ini hasil pemangkasan titonia digunakan untuk perlakuan penelitian lainnya.

Berdasarkan hasil penelitian pada Tablel 1) menurut Rosnarkam da Yuwono (2002), ternyata Al-dd berada pada kisaran sangat rendah. Pada perlakuan pagar lorong (R1) terjadi penurunan sebesar $1 \mathrm{me} / 100 \mathrm{~g}$ dari periode pangkas 2 bulan ke 4 bulan, sedangkan pada perlakuan pagar kebun (R2) terjadi kenaikan Al-dd sebesar 1,75 me/100 g dari periode pangkas 2 bulan ke 4 bulan Rendahnya kandungan Al-dd pada tanah Ultisol sangat dipengaruhi oleh $\mathrm{pH}$ tanah. Menurut Hakim et al (1986) pada pH tanah yang rendah, Al menjadi sangat mudah larut dalam tanah dan akan menjadi racun bagi tanaman. Keracunan Al menyebabkan terganggunya pertumbuhan akar baik morfologi maupun fisiologinya yang pada akhirnya akan mengoangou serapan har tanaman.

Pertumbu

\section{Dari Thonia diversifolia}


tanaman harameter periode pangkas berpengaruh nyata pada 
jumlah cabang, jumlah daun, bobot segar dan kering serta hasil $\mathrm{N}, \mathrm{P}, \mathrm{K}, \mathrm{Ca}$ dan $\mathrm{Mg}$ titonia. Dari pengamatan lapangan didapatkan fakta bahwa pertumbuhan titonia di lapangan sangat bagus, ini dapat dilihat pada Gambar 1. Titonia yang dibudidayakan dengan perlakuan pagar lorong jarak $5 \mathrm{~m}$ dan pagar kebun $10 \mathrm{~m} \times 10$ $\mathrm{m}$ memperlihatkan pertumbuhan yang baik.

Pada Gambar 1 terlihat bahwa pada periode pangkas 2 bulan, belum ada bunga yang mekar (Gambar 1A dan 1B), namun pada periode pangkas 4 bulan, bunga sudah mekar (Gambar 1C). Hakim dan Agustian (2005), melaporkan setelah satu tahun pengamatan, berdasarkan hasil bahan kering, serta unsur hara yang dihasilkan dari titonia adalah tanaman yang mempunyai keistimewaan dalam menyerap unsur hara dan pertumbuhan, meskipun tidak mempunyai bintil akar seperti tanaman legum.

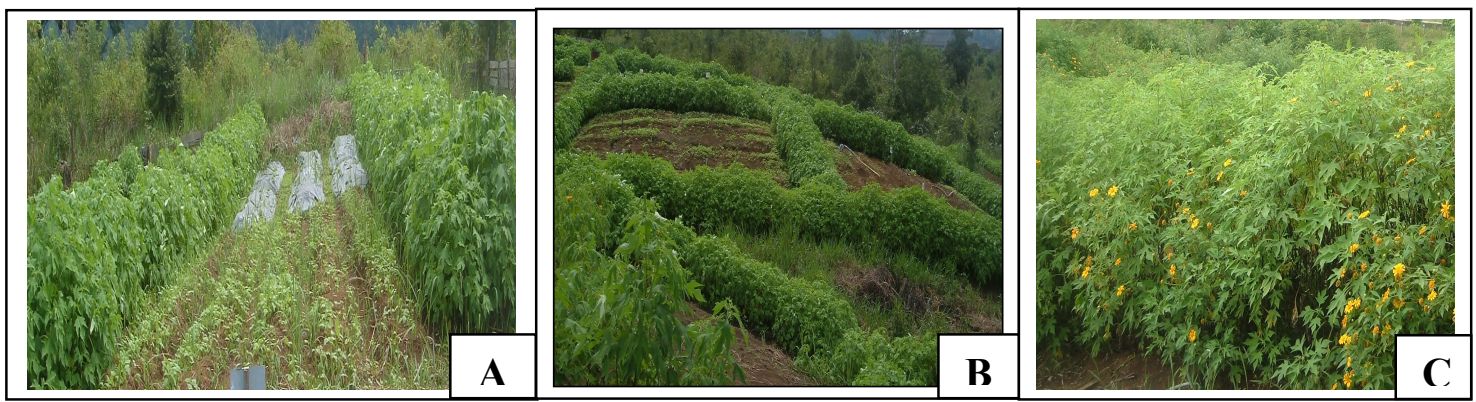

Gambar 1. Pertumbuhan titonia umur 2 bulan pada Ultisol Limau Manis Padang, berdasarkan rancangan baris tanam pagar lorong berjarak $5 \mathrm{~m}$ (A), pagar kebun $10 \mathrm{mx} 10 \mathrm{~m}$ (B), dan ketika berumur 4 bulan (C)

Pada penelitian ini sampel tanaman diambil sebanyak $1 \mathrm{~m}^{2}$ dan kemudian dikonversikan dengan satuan hektar. Pada perlakuan pagar lorong jarak $5 \mathrm{~m}$ (R1) didapatkan 20 baris dalam 1 ha (20 baris vertikal ha ${ }^{-1}=2000 \mathrm{~m}^{-2}$ ) sedangkan pada perlakuan pagar keliling kebun $10 \mathrm{~m} \times 10 \mathrm{~m}$ didapatkan 10 baris horizontal dan 10 baris vertikal (10 baris horizontal dan 10 baris vertikal ha-1 $=1900 \mathrm{~m}^{-2}$ ).

\section{Biomasa Tithonia diversifolia}

Dari analisis ragam dapat dinyatakan bahwa pola baris tanam tidak berpengaruh nyata dalam meningkatkan jumlah cabang, tapi dipengaruhi secara nyata oleh periode pangkas (Tablel 2). Rancangan baris pagar kebun $10 \mathrm{~m}$ x $10 \mathrm{~m}$, berbeda tidak nyata dengan rancangan baris pagar lorong jarak $5 \mathrm{~m}$. Sedangkan periode pangkas 2 bulan (U1) berbeda nyata dengan periode pangkas 4 bulan (U2).

Pada (Tablel 2) memperlihatkan bahwa pagar lorong jarak 5 m meningkatkan jumlah cabang secara tidak nyata sebesar 67.00 cabang/rumpun dibanding pagar kebun $10 \mathrm{~m}$ x $10 \mathrm{~m}$ yang hanya 58.99 cabang/rumpun. Pengaruh periode pangkas terhadap jumlah cabang secara nyata meningkatkan jumlah cabang/rumpun. Pada periode pangkas 2 bulan jumlah cabang titonia hanya 39.33 cabang/rumpun Ini berbeda nyata sebesar 47.33 cabang/rumpun dibandingkan dengan periode pangkas 4 bulan yang berjumlah 86.66 cabang/rumpun.

Perbedaan jumlah cabang/rumpun ini terjadi karena adanya perpanjangan periode pangkas dari 2 bulan ke 4 bulan, dimana pada periode pangkas 2 bulan terjadi 2 kali pemangkasan sehingga cabang titonia yang baru dipangkas baru mulai tumbuh dibandingkan dengan umur pangkas 4 bulan yang telah mengalami pertumbuhan yang lebih lama. Titonia yang berumur 4 bulan ini berdasarkan pengamatan di lapangan batangnya rebah akibat kuntum bunga yang lebat dan daun kecil-kecil yang banyak. Pada periode pangkas 4 bulan, sebagian besar daun bawah dan sebagian bunga sudah mongering, tunas dan daun baru muncul dari ketiak daun yang sudah mati itu Daun yang jatuh di sekitar batang akan melapuk dan meningkatkan kesuburan tanah yang terdapat dibawahnya. Apabila lahan yang ditumbuhi titonia dalam waktu yang cukup lama diolah untuk diusahakan, maka akan diperoleh pertumbuhan yang bagus dan hasil yang tinggi. Dengan sifat seperti itu titonia berpotensi besar untuk dijadikan tanaman pionir pada program rehabilitasi lahan kritis 
atau reboisasi tahap awal (Hakim dan Agustian, 2005).

Deswita (2005) menemukan bahwa titonia yang ditanam dilapangan menghasilkan jumlah cabang titonia ratarata 57.87 cabang/rumpun. Sedangkan dalam penelitian lapangan ini rata-rata jumlah cabang titonia 39.33 cabang/rumpun pada periode pangkas 2 bulan dan 86.66 cabang/rumpun pada periode pangkas 4 bulan atau rata-rata jumlah cabang titonia 62.99 cabang/rumpun. Terjadinya perbedaan ini diduga adanya perbedaan dalam periode pangkas, dimana periode pangkas yang dilakukan oleh Deswita (2005) adalah periode pangkas 2 bulan selama 4 bulan. sehingga didapatkan dua kali pemangkasan.

Dari analisis ragam diketahui bahwa rancangan baris tanam tidak berpengaruh nyata dalam meningkatkan jumlah daun. Tablel 2 menyatakan bahwa jumlah daun pada periode pangkas 4 bulan lebih tinggi secara nyata (270 lembar) di banding jumlah daun pada periode pangkas 2 bulan.

Tablel 2 Pengaruh rancangan baris dan periode pangkas terhadap jumlah cabang Titonia selama 4 bulan pengamatan pada Ultisol Limau Manis, Padang

\begin{tabular}{lcc}
\hline \multicolumn{1}{c}{ Perlakuan } & $\begin{array}{c}\text { Jumlah cabang } \\
\text { (cabang/rumpun) }\end{array}$ & $\begin{array}{c}\text { Jumlah daun } \\
\text { (helai/rumpun) }\end{array}$ \\
\hline Rancangan baris tanam (R) & & \\
Pagar lorong jarak 5 m (R1) & $67.00 \mathrm{a}$ & $325.75 \mathrm{a}$ \\
Pagar kebun 10m x 10m (R2) & $58.99 \mathrm{a}$ & $337.67 \mathrm{a}$ \\
\hline KK (R) $=$ & $6.14 \%$ & $6.81 \%$ \\
\hline Periode Pangkas (U) & & \\
Periode pangkas 2 bulan (U1) & $39.33 \mathrm{~b}$ & $196.75 \mathrm{~b}$ \\
Periode pangkas 4 bulan (U2) & $86.66 \mathrm{a}$ & $466.67 \mathrm{a}$ \\
\hline KK (U) $=$ & $6.88 \%$ & $18.27 \%$ \\
\hline
\end{tabular}

Angka - angka pada kolom yang sama yang diikuti oleh huruf kecil yang sama adalah berbeda tidak nyata menurut BNT pada taraf $5 \%$

\section{Biomasa Tithonia diversifolia}

Dari analisis ragam diketahui bahwa rancangan baris tanam dan periode pangkas tidak berpengaruh nyata terhadap bobot segar titonia. Hasil biomasa segar untuk pemangkasan 2 bulan adalah total untuk 2 kali pemangkasan. sedangkan periode pangkas 4 bulan untuk 1 kali pangkas (Tablel 3) memperlihatkan bahwa rancangan baris tanam pagar lorong jarak $5 \mathrm{~m}$ dan pagar kebun $10 \mathrm{~m} \times 10 \mathrm{~m}$ sama baiknya dalam menghasilkan bobot segar. Ditinjau dari periode pangkas 2 dan 4 bulan juga
Pada Tablel 2 terlihat bahwa dari sudut rancangan baris tanam, secara umum pagar kebun $10 \mathrm{~m}$ x $10 \mathrm{~m}$ menghasilkan jumlah daun terbanyak (338 helai/rumpun). Jumlah daun tersebut sebanyak 12 helai lebih banyak dari pagar lorong yang hanya sekitar 326 helai/rumpun, tetapi tidak berbeda nyata. Sedangkan bila ditinjau dari segi periode pangkas. pemangkasan yang dilakukan setelah 4 bulan menghasilkan jumlah daun terbanyak dibanding periode pangkas 2 bulan. Dari (Tablel 2) dapat dijelaskan bahwa jumlah daun berbeda nyata sebanyak 197 helai/rumpun pada periode pangkas 2 bulan. dan sebanyak 466.666 helai/rumpun pada periode pangkas 4 bulan.

Berdasarkan data dalam Tablel 2 maka dapat disimpulkan bahwa periode pangkas yang terbaik dalam jumlah cabang dan daun terbanyak adalah periode pangkas 4 bulan yaitu sebanyak 87 cabang/rumpun dan 467 helai/rumpun. 
secara tidak nyata (10.95 ton/ha) pada periode pangkas 2 bulan dan (11.55 ton/ha) pada periode pangkas 4 bulan.

Kecendrungan meningkatnya bobot segar titonia dengan semakin diperpanjang nya periode pangkas, disebabkan oleh mulai mengayunya batang bagian bawah titonia pada periode pangkas 4 bulan. Hal ini seiring dengan pendapat Hakim dan
Agustian (2003) yang mengemukakan bahwa umur pangkas 4 bulan menghasilkan biomasa dan unsur hara lebih tinggi. Namun biomassa yang lebih besar pada periode pangkas 4 bulan disebabkan oleh karena batang bawah yang sudah agak keras dan agak sukar melapuk, sedangkan bagian atasnya sudah mulai berbunga.

Tablel 3. Pengaruh rancangan baris dan periode pangkas terhadap bobot segar dan kering Titonia selama 4 bulan pengamatan pada Ultisol Limau Manis. Padang

\begin{tabular}{lcc}
\hline \multicolumn{1}{c}{ Perlakuan } & $\begin{array}{c}\text { Bobot segar } \\
\text { (ton/ha) }\end{array}$ & $\begin{array}{c}\text { Bobot kering } \\
\text { (ton/ha) }\end{array}$ \\
\hline Rancangan baris tanam (R) & & \\
Pagar lorong jarak 5 m (R1) & $12.223 \mathrm{a}$ & $2.19 \mathrm{a}$ \\
Pagar kebun 10m x 10m (R2) & $10.268 \mathrm{a}$ & $1.96 \mathrm{a}$ \\
\hline KK (R) $=$ & $36.29 \%$ & $8.50 \%$ \\
\hline Periode Pangkas (U) & & \\
Periode pangkas 2 bulan (U1) & $10.947 \mathrm{a}$ & $2.24 \mathrm{a}$ \\
Periode pangkas 4 bulan (U2) & $11.545 \mathrm{a}$ & $1.91 \mathrm{a}$ \\
\hline KK (U) $=$ & $33.88 \%$ & $15.37 \%$ \\
\hline
\end{tabular}

Angka - angka pada kolom yang sama yang diikuti oleh huruf kecil yang sama adalah berbeda tidak nyata menurut BNT pada taraf $5 \%$

Hakim dan Agustian (2003) menemukan bahwa titonia yang tumbuh alami di lapangan rata-rata bobot segarnya $3,28 \mathrm{~kg} / \mathrm{m}^{2}$. Sedangkan dalam penelitian ini rata-rata bobot segarnya bila dikonversikan ke dalam $\mathrm{kg} / \mathrm{m}^{2}$, pada perlakuan pagar lorong jarak $5 \mathrm{~m}$ dan periode pangkas 2 bulan adalah $5,52 \mathrm{~kg} / \mathrm{m}^{2}$ dan sebesar 6,70 $\mathrm{kg} / \mathrm{m}^{2}$ pada periode pangkas 4 bulan. Namun pada perlakuan pagar kebun $10 \mathrm{~m} \mathrm{x}$ $10 \mathrm{~m}$ terjadi penurunan bobot segar rata-rata dari $5,71 \mathrm{~kg} / \mathrm{m}^{2}$ pada periode pangkas 2 bulan menjadi $5,10 \mathrm{~kg} / \mathrm{m}^{2}$ pada pangkasan 4 bulan. Hal ini mungkin disebabkan oleh kesuburan tanahnya dan juga perbedaan umur titonia. Bila dibandingkan dengan hasil penelitian pot oleh Zamora (2004), melaporkan bahwa rata-rata bobot segar titonia $1,29 \mathrm{~kg} / \mathrm{m}^{2}$, maka hasil penelitian ini lebih besar.

Secara umum tampaknya pagar lorong jarak $5 \mathrm{~m}$ memberikan biomasa kering tertinggi $\left(2,19\right.$ ton $\left.\mathrm{ha}^{-1}\right)$. Hasil tersebut sebanyak 0,23 ton ha ${ }^{-1}$ lebih tinggi dari pada hasil pagar kebun $10 \mathrm{~m} \times 10$ yang hanya sekitar 1,96 ton $\mathrm{ha}^{-1}$. Hasil pengamatan Hakim dan Agustian (2005) terhadap bobot kering titonia yang dilakukan selama satu tahun pengamatan dimana untuk pangkasan 2 bulan didapatkan sebanyak 6 kali pangkas menghasilkan biomasa kering 5,9 ton ha-1 pada pagar lorong. dan sebanyak 5,0 ton ha- ${ }^{-1}$ pada pagar kebun $10 \mathrm{~m}$ x $10 \mathrm{~m}$.

Pangkasan 2 bulan menghasilkan bobot kering titonia tertinggi yaitu sebanyak 2.238 ton $\mathrm{ha}^{-1}$. Biomasa kering tersebut berbeda tidak nyata sebanyak 0,33 ton $\mathrm{ha}^{-1}$ dibanding periode pangkas 4 bulan yang sebanyak 1,91 ton $\mathrm{ha}^{-1}$. Adanya perbedaan pada bobot kering pada periode pangkas 4 bulan (U2) dengan jumlah cabang dan jumlah daun diduga karena pengaruh kadar air pada titonia. Kadar air yang tinggi pada titonia dengan periode pangkas 4 bulan diduga mempengaruhi bobot kering titonia menjadi lebih kecil dibandingkan bobot kering titonia pada periode pangkas 2 bulan.

Hasil bobot kering titonia pada memperlihatkan bahwa rancangan baris tanam pagar lorong jarak $5 \mathrm{~m}$ sama baiknya dengan pagar kebun $10 \mathrm{~m} \times 10 \mathrm{~m}$. Ditinjau pada periode pangkas dari 2 dan 4 bulan juga sama baiknya.

Walaupun jumlah cabang dan jumlah daun lebih tinggi pada periode pangkas 4 bulan. namun berat kering tertinggi 
didapatkan pada periode pangkas 2 bulan (2.24 ton/ha). Lebih tingginya bobot kering pada periode pangkas 2 bulan diduga karena pengaruh pemangkasan. Pada periode pangkas 2 bulan didapatkan dua kali pemangkasan sedangkan pada periode pangkas 4 bulan didapatkan satu kali pemangkasan. Seperti diketahui, salah satu keunggulan titonia adalah memiliki ketahanan terhadap pemangkasan. Setelah pemangkasan biasanya titonia akan lebih cepat tumbuh kembali. Selain itu kadar air yang tinggi diduga menjadi faktor lain yang menyebabkan rendahnya bobot kering pada periode pangkas 4 bulan.

Pada penelitian lapangan ini bila bobot kering di konversikan dalam $\mathrm{kg} / \mathrm{m}^{2}$, maka diperoleh bobot kering titonia tertinggi sebanyak $1,20 \quad \mathrm{~kg} / \mathrm{m}^{2}$ untuk 2 kali pemangkasan. Bila dalam satu tahun titonia dapat dipangkas sebanyak 6 kali, maka dihasilkan bobot kering sekitar $3,60 \mathrm{~kg} / \mathrm{m}^{2}$ /tahun. Berarti bobot kering dalam penelitian ini lebih besar daripada di Kenya Afrika. Lauriks et al (1999 cit Hakim dan Agustian, Kandungan Hara Tithonia diversifolia
2003) melaporkan bahwa di Kenya titonia yang ditanam sebagai pagar pembatas kebun menghasilkan bobot kering sekitar 1 $\mathrm{kg} / \mathrm{m}^{2} /$ tahun. Hal ini diduga disebabkan oleh curah hujan di Sumatera Barat yang tinggi yaitu sekitar $5500 \mathrm{~mm} /$ tahun (Hakim dan Agustian, 2005) sehingga air tersedia terus untuk pertumbuhan titonia.

Berdasarkan data diperoleh dapat disimpulkan bahwa bobot segar tertinggi adalah pagar lorong jarak $5 \mathrm{~m}$ dengan periode pangkas 4 bulan $\left(12.2 \mathrm{t} \mathrm{ha}^{-1}\right)$. Sedangkan bobot kering tertinggi dari pagar lorong jarak $5 \mathrm{~m}$ (2.19 ton $\left.\mathrm{ha}^{-1}\right)$ dengan periode pangkas 2 bulan $\left(2.24\right.$ ton $\left.\mathrm{ha}^{-1}\right)$.

Berdasarkan analisis ragam terlihat bahwa rancangan baris tanam tidak berpengaruh nyata terhadap hasil $\mathrm{N}$ titonia, tetapi periode pangkas berpengaruh nyata pada hasil $\mathrm{N}$ titonia. Dari Tablel 4 dapat dinyatakan bahwa dari segi rancangan barisan, rancangan pagar lorong jarak $5 \mathrm{~m}$ memberikan hasil $\mathrm{N}$ tertinggi sebesar 55.464 $\mathrm{kg} / \mathrm{ha}$. Hasil ini lebih besar $7.884 \mathrm{~kg} / \mathrm{ha}$

Tablel 4. Pengaruh rancangan baris dan periode pangkas terhadap hasil $\mathrm{N}$ Tithonia selama 4 bulan pengamatan pada Ultisol Limau Manis. Padang

\begin{tabular}{lccc}
\hline \multicolumn{1}{c}{ Perlakuan } & $\begin{array}{c}\text { Hasil N } \\
(\mathrm{kg} / \mathrm{ha})\end{array}$ & $\begin{array}{c}\text { Hasil Ca } \\
(\mathrm{kg} / \mathrm{ha})\end{array}$ & $\begin{array}{c}\text { Hasil Mg } \\
(\mathrm{kg} / \mathrm{ha})\end{array}$ \\
\hline Rancangan baris tanam (R) & & & \\
Pagar lorong jarak 5 m (R1) & $55.46 \mathrm{a}$ & $9.276 \mathrm{a}$ & $4.256 \mathrm{a}$ \\
Pagar kebun 10m x 10m (R2) & $47.62 \mathrm{a}$ & $8.626 \mathrm{a}$ & $3.677 \mathrm{a}$ \\
\hline KK (R) & $2.01 \%$ & $25.78 \%$ & $26.878 \%$ \\
\hline Periode Pangkas (U) & & & \\
Periode pangkas 2 bulan (U1) & $62.82 \mathrm{a}$ & $13.359 \mathrm{a}$ & $5.472 \mathrm{a}$ \\
Periode pangkas 4 bulan (U2) & $40.26 \mathrm{~b}$ & $4.543 \mathrm{~b}$ & $2.462 \mathrm{~b}$ \\
\hline KK (U) $=$ & $5.32 \%$ & $31.22 \%$ & $21.407 \%$ \\
\hline
\end{tabular}

Angka - angka pada kolom yang sama yang diikuti oleh huruf kecil yang sama adalah berbeda tidak nyata menurut BNT pada taraf $5 \%$

dibandingkan dengan pagar kebun $10 \mathrm{~m}$ x 10 $\mathrm{m}$ yang hanya $47.62 \mathrm{~kg} / \mathrm{ha}$. Dilain pihak, perpanjangan umur pangkas dari 2 bulan ke 4 bulan menurunkan hasil secara nyata sebesar $22.53 \mathrm{~kg} / \mathrm{ha}$ dari $62.82 \mathrm{~kg} / \mathrm{ha}$ pada periode pangkas 2 bulan menjadi 40.26 $\mathrm{kg} / \mathrm{ha}$ pada periode pangkas 4 bulan Lebih tingginya hasil $\mathrm{N}$ pada perlakuan pagar lorong jarak $5 \mathrm{~m}$ diduga disebabkan oleh sumbangan unsur hara $\mathrm{N}$ yang berasal dari limpahan pupuk $\mathrm{N}$ dari petak tanaman utama dalam lorong yang lebarnya hanya $5 \mathrm{~m}$, atau dari petak $10 \mathrm{~m} \times 10 \mathrm{~m}$. Di samping itu ,dapat pula disebabkan oleh kurangnya persaingan sinar matahari sesamanya karena tanaman berkembang bebas pada lebar baris tanaman $1 \mathrm{~m}$.

Pada (Tablel 4) memperlihatkan bahwa dari segi rancangan barisan, pagar lorong jarak $5 \mathrm{~m}$ menghasilkan $\mathrm{Ca}$ sebesar $9.276 \mathrm{~kg} / \mathrm{ha}$. Hal ini berbeda tidak nyata sebesar $0,65 \mathrm{~kg} / \mathrm{ha}$ dibandingkan dengan 
pagar kebun $10 \mathrm{~m} \times 10 \mathrm{~m}$ yang memberikan hasil Ca sebesar $8.63 \mathrm{~kg} / \mathrm{ha}$. Periode pangkas 2 bulan menghasilkan $\mathrm{Ca}$ lebih banyak sebesar $8.82 \mathrm{~kg} / \mathrm{ha}$ dibandingkan pangkasan 4 bulan. Tingginya hasil $\mathrm{Ca}$ pada perlakuan seperti tersebut diatas erat kaitannya dengan bobot kering yang didapatkan. Bobot kering titonia tertinggi juga didapatkan pada perlakuan tersebut sehingga hasil $\mathrm{Ca}$ yang diperoleh pada perlakuan tersebut juga tinggi.

Zamora (2004) melaporkan. bahwa titonia yang ditanam dalam pot mempunyai rata-rata kandungan $\mathrm{Ca} 0.61 \%$. Berarti hasil $\mathrm{Ca}$ pada penelitian ini lebih rendah daripada penelitian pot. karena kadar $\mathrm{Ca}$ hanya sebesar $0.42 \%$. sedangkan bila dibandingkan dengan hasil pengamatan. Hakim dan Agustian (2004) yang melaporkan bahwa tajuk berdaun $70 \mathrm{~cm}$ teratas titonia mengandung $0.24 \% \mathrm{Ca}$, maka kadar Ca pada penelitian ini lebih besar. Hal ini mungkin terjadi akibat adanya pemberian pupuk awal pada penelitian lapangan, sedangkan yang tumbuh alami di lapangan tanpa input pupuk.

Berdasarkan analisis ragam rancangan baris tanam tidak berpengaruh nyata terhadap hasil $\mathrm{Mg}$ titonia, tetapi periode pangkas berpengaruh nyata. Pada Tablel 4 dapat dilihat bahwa perpanjangan periode pangkas dari 2 bulan ke 4 bulan menurunkan hasil $\mathrm{Mg}$ secara nyata sebesar $3.010 \mathrm{~kg} / \mathrm{ha}$. Pada pada pagar lorong jarak $5 \mathrm{~m}$ hasil lebih tinggi $0.579 \mathrm{~kg} / \mathrm{ha}$ dibandingkan pagar kebun $10 \mathrm{~m} \times 10 \mathrm{~m}$. Hal ini juga berkaitan erat dengan bobot kering yang didapatkan Bobot kering tertinggi juga diperoleh pada pagar lorong jarak $5 \mathrm{~m}$.

Rata-rata kandungan $\mathrm{Mg}$ pada penelitian ini adalah $0.18 \%$. Deswita (2005) melaporkan bahwa kandungan hara $\mathrm{Mg}$ ratarata $0.23 \%$ dari penelitian yang dilakukannya. Hasil ini relatif sama, namun bila dibandingkan dengan hasil pengamatan Hakim dan Agustian (2003) dimana rata-rata kandungan titonia yang tumbuh alami dilapangan (tajuk berdaun diatas $70 \mathrm{~cm}$ ) adalah $0.51 \%$. Berarti hasil penelitian ini lebih rendah. Hal ini mungkin disebabkan oleh perbedaan kesuburan tanah dan umur titonia yang diamati. Titonia yang tumbuh secara alami dilapangan sudah tua dan mengalami beberapa kali pemangkasan, sedangkan penelitian ini baru melakukan 2 kali pemangkasan pada umur titonia 2 bulan dan 1 kali pada periode pangkas 4 bulan.

Dari hasil-hasil pengamatan yang telah dikemukakan, dapat dinyatakan bahwa secara umum rancangan baris tanam titonia sebagai pagar lorong jarak $5 \mathrm{~m}$ dengan periode pangkas 2 bulan adalah terbaik dalam menghasilkan bahan organik kering dan unsur hara $\mathrm{N}, \mathrm{Ca}$, dan $\mathrm{Mg}$. Sedangkan baris tanam titonia pagar kebun $10 \mathrm{~m} \times 10 \mathrm{~m}$ dengan periode pangkas 2 bulan terbaik dalam menghasilkan unsur $\mathrm{P}$ dan K. Akan tetapi. pada baris tanam $10 \mathrm{~m} \times 10 \mathrm{~m}$ dan pada pagar lorong yang berjarak $5 \mathrm{~m}$ tidak menunjukkan perbedaan yang nyata untuk semua parameter yang diamati. Oleh karena itu. kedua rancangan barisan tersebut dapat digunakan untuk budidaya titonia di lapangan. Pernyataan ini dapat didukung dengan hasil pengamatan. Hakim dan Agustian (2005) selama satu tahun. Mereka juga menyatakan bahwa kedua rancangan baris tanam pagar lorong jarak $5 \mathrm{~m}$ dan pagar kebun $10 \mathrm{~m} \times 10 \mathrm{~m}$, sama baiknya dalam menghasilkan bahan organik dan unsur hara.

Lain halnya dengan umur pangkas 2 bulan dan 4 bulan yang berbeda nyata dalam menghasilkan bahan kering dan unsur hara Dalam hal ini. periode pangkas 2 bulan memberikan hasil bahan kering. hasil hara $\mathrm{N}$. P. K. Ca dan $\mathrm{Mg}$ yang jauh lebih tinggi dan nyata dibandingkan dengan periode pangkas 4 bulan. Dengan demikian dapat disimpulkan bahwa umur pangkas titonia yang tepat adalah setiap 2 bulan. Sedangkan rancangan pola baris tanam baik dalam bentuk pagar lorong jarak $5 \mathrm{~m}$ dan boleh juga dalam bentuk pagar kebun $10 \mathrm{~m}$ x $10 \mathrm{~m}$.

Hasil bahan organik kering sebesar 2 ton/ha selama 4 bulan pengamatan cukup menarik untuk dibahas. Budidaya secara terus menerus dan periodik tithonia dapat menghasilkan bahan organik di lahan usaha sebanyak 2 ton/ha, diikuti dengan hasil $\mathrm{N}$ sekitar $60 \mathrm{~kg} / \mathrm{ha}$, dan sebesar $80 \mathrm{~kg} / \mathrm{ha}$. Dengan demikian budidaya titonia di lahan usaha akan dapat menghemat pengeluaran petani untuk penggunaan pupuk.

Berdasarkan hasil penelitian dapat disimpulkan bahwa untuk mendapatkan 
hasil $\mathrm{N}, \mathrm{Ca}$, dan $\mathrm{Mg}$ tertinggi dari titonia dapat dipakai rancangan barisan pagar lorong jarak $5 \mathrm{~m}(55.464 \mathrm{~kg} / \mathrm{ha})$ dengan periode pangkas 2 bulan.

\section{Hasil Analisis Kandungan P dan K Tithonia diversifolia}

Berdasarkan analisis ragam dapat dinyatakan bahwa hasil $\mathrm{P}$ dipengaruhi secara nyata oleh periode pangkas, sedangkan rancangan barisan yang tidak berpengaruh nyata Interaksi keduanya juga berpengaruh nyata.

Pengaruh interaksi yang nyata pada Tablel 5 dapat dijelaskan bahwa pada perlakuan pagar lorong jarak $5 \mathrm{~m}$. Perpanjangan umur pangkas dari 2 bulan ke 4 bulan menurunkan hasil secara tidak nyata sebesar $2,00 \mathrm{~kg} / \mathrm{ha}$ dari $14,56 \mathrm{~kg} / \mathrm{ha}$ pada periode pangkas 2 bulan menjadi $12,56 \mathrm{~kg} / \mathrm{ha}$ pada periode pangkas 4 bulan. Sedangkan pada pagar kebun $10 \mathrm{~m} \times 10 \mathrm{~m}$ perpanjangan periode pangkas dari 2 bulan ke 4 bulan menurunkan hasil P titonia secara nyata sebesar 10.479 $\mathrm{kg} / \mathrm{ha}$ dari $20.784 \mathrm{~kg} / \mathrm{ha}$ pada periode pangkas 2 bulan menjadi $10.305 \mathrm{~kg} / \mathrm{ha}$ pada periode pangkas 4 bulan Selanjutnya pada periode pangkas 2 bulan hasil pada pagar kebun $10 \mathrm{~m}$ x $10 \mathrm{~m}(20.784 \mathrm{~kg} / \mathrm{ha})$ lebih besar dari pada pagar lorong jarak $5 \mathrm{~m}$ $(14.556 \mathrm{~kg} / \mathrm{ha})$ secara nyata sebesar 6.228 $\mathrm{kg} / \mathrm{ha}$. sedangkan pada periode pangkas 4 bulan. pagar kebun $10 \mathrm{~m}$ x $10 \mathrm{~m}(10.305$ $\mathrm{kg} / \mathrm{ha}$ ) menurunkan hasil secara tidak nyata sebesar $2.254 \mathrm{~kg} / \mathrm{ha}$ dibanding pagar lorong jarak $5 \mathrm{~m}(12.559 \mathrm{~kg} / \mathrm{ha})$

Dari uraian diatas, lebih tingginya hasil P pada perlakuan periode pangkas 2 bulan diduga karena dilakukannya input pupuk awal sebelum penanaman titonia dan juga karena adanya limpahan pupuk $\mathrm{P}$ dari petak tanaman utama dalam lorong yang lebarnya hanya $5 \mathrm{~m}$ atau dari petak $10 \mathrm{~m} \mathrm{x}$ Tablel 5. Pengaruh rancangan baris dan periode pangkas serta interaksi keduanya terhadap hasil P Titonia selama 4 bulan pengamatan pada Ultisol Limau Manis. Padang

\begin{tabular}{|c|c|c|}
\hline \multirow{2}{*}{$\begin{array}{l}\text { Rancangan } \\
\text { Baris tanam }\end{array}$} & \multicolumn{2}{|c|}{ Umur pangkas } \\
\hline & 2 bulan & 4 bulan \\
\hline & \multicolumn{2}{|c|}{. hasil P $(\mathrm{kg} / \mathrm{ha}) \ldots$} \\
\hline Pagar lorong jarak $5 \mathrm{~m}$ & $14.556 \mathrm{Ab}$ & $12.559 \mathrm{Aa}$ \\
\hline Pagar kebun $10 \mathrm{~m} \times 10 \mathrm{~m}$ & $20.784 \mathrm{Aa}$ & $10.305 \mathrm{Ba}$ \\
\hline \multicolumn{3}{|l|}{$\mathrm{KK}=19.340 \%$} \\
\hline & \multicolumn{2}{|c|}{... hasil $\mathrm{K}(\mathrm{kg} / \mathrm{ha})$. } \\
\hline Pagar lorong jarak $5 \mathrm{~m}$ & $72.577 \mathrm{Aa}$ & $59.903 \mathrm{Aa}$ \\
\hline Pagar kebun $10 \mathrm{~m} \times 10 \mathrm{~m}$ & $89.552 \mathrm{Aa}$ & $37.520 \mathrm{Bb}$ \\
\hline
\end{tabular}

Angka - angka pada kolom yang sama yang diikuti oleh huruf kecil yang sama dan pada baris yang sama diikuti oleh huruf besar yang sama adalah berbeda tidak nyata menurut BNT pada taraf $5 \%$

10m. Dari hasil $\mathrm{P}$ titonia nampak bahwa pagar kebun $10 \mathrm{~m}$ x $10 \mathrm{~m}$ pada periode pangkas 2 bulan memberikan hasil P titonia tertinggi yaitu $20.784 \mathrm{~kg} / \mathrm{ha}$. Hal ini sudah sejalan dengan hasil $\mathrm{N}$ dan bobot kering yang telah dijelaskan terdahulu. Dalam hal ini bobot kering dan hasil $\mathrm{N}$ tertinggi juga diperoleh pada rancangan baris tanam pagar kebun $10 \mathrm{~m}$ x $10 \mathrm{~m}$ dengan umur pangkas 2 bulan.

Pada penelitian lapangan ini. titonia yang ditanam mengandung $0.69 \% \mathrm{P}$ Bila dibandingkan dengan penelitian pot yang dilakukan oleh Zamora (2004) yang melaporkan bahwa titonia yang ditanam dalam pot rata-rata mengandung $0.19 \% \mathrm{P}$. Berarti hasil penelitian lapangan ini lebih besar dari pada penelitian pot. Perbedaan media tumbuh diduga menjadi salah satu alasan terjadinya perbedaan kandungan $\mathrm{P}$ titonia. Media didalam pot lebih terbatas dalam perkembangan akar dan penyerapan unsur hara, sedangkan di lapangan akar berkembang bebas.

Berdasarkan analisis ragam hasil $\mathrm{K}$ titonia dipengaruhi secara nyata oleh periode pangkas. Sebelumnya, rancangan barisan 
yang berpengaruh nyata, interaksi keduanya juga berpengaruh nyata.

Pada (Tablel 5) terlihat bahwa pagar lorong jarak $5 \mathrm{~m}$ dapat meningkatkan hasil $\mathrm{K}$ titonia secara tidak nyata sebesar 2,70 $\mathrm{kg} / \mathrm{ha}$ dibanding pagar kebun $10 \mathrm{~m} \times 10 \mathrm{~m}$ Bila dibandingkan dengan periode pangkas terjadi penurunan hasil $\mathrm{K}$ titonia secara nyata dari pangkasan 2 bulan ke 4 bulan sebesar $32.35 \mathrm{~kg} / \mathrm{ha}$.

Pengaruh interaksi yang nyata pada (Tablel 5) dapat dijelaskan, bahwa pada pagar lorong jarak $5 \mathrm{~m}$, perpanjangan umur pangkas dari 2 bulan ke 4 bulan menurunkan hasil secara tidak nyata sebesar $12,67 \mathrm{~kg} / \mathrm{ha}$ dari $72,58 \mathrm{~kg} / \mathrm{ha}$ pada periode pangkas 2 bulan menjadi $59,90 \mathrm{~kg} / \mathrm{ha}$ pada periode pangkas 4 bulan. Sebaliknya pada pagar kebun $10 \mathrm{~m} \times 10 \mathrm{~m}$ terjadi penurunan hasil $\mathrm{K}$ secara nyata sebesar $52,03 \mathrm{~kg} / \mathrm{ha}$ dari $89,55 \mathrm{~kg} / \mathrm{ha}$ pada periode pangkas 2 bulan menjadi $37,52 \mathrm{~kg} / \mathrm{ha}$ pada periode pangkas 4 bulan. Selanjutnya pada periode pangkas 2 bulan, hasil pada pagar kebun $10 \mathrm{~m} \times 10 \mathrm{~m}$ lebih besar $(89,55 \mathrm{~kg} / \mathrm{ha})$ secara tidak nyata sebesar $16,98 \mathrm{~kg} / \mathrm{ha}$ dibanding pagar lorong jarak $5 \mathrm{~m}(72,58 \mathrm{~kg} / \mathrm{ha})$. Pada periode pangkas 4 bulan, terjadi penurunan hasil $\mathrm{K}$ secara nyata sebesar $22,38 \mathrm{~kg} / \mathrm{ha}$ pada pagar kebun $10 \mathrm{mx} 10 \mathrm{~m}$ bila dibandingkan dengan pagar lorong jarak $5 \mathrm{~m}$.

Lebih tingginya hasil $\mathrm{K}$ pada perlakuan pagar kebun $10 \mathrm{~m} \times 10 \mathrm{~m}$ diduga karena pengaruh limpahan pupuk dari petak tanaman utama. Selain itu dapat pula disebabkan oleh kurangnya persaingan sinar matahari antar sesamanya karena tanaman dapat berkembang bebas pada lebar baris tanam $1 \mathrm{~m}$.

Dari penelitian ini didapatkan ratarata kadar unsur $\mathrm{K}$ pada titonia sebesar $3.077 \% \mathrm{~K}$. Bila dibandingkan dengan yang dilaporkan oleh Jama et al (2000) dan Rutunga (1999) bahwa titonia yang tumbuh di Kenya daun hijaunya mengandung unsur hara sebesar $3.5-4 \% \mathrm{~K}$, maka pada hasil penelitian ini sedikit lebih rendah. Hal ini diduga akibat perbedaan pada bagian tanaman yang dianalisis. Dalam penelitian ini batang dan daun titonia dicampur sehingga tidak bisa dipastikan komposisi kadar hara $\mathrm{K}$ pada batang dan daun. Hakim dan Agustian (2005) yang melakukan pengamatan selama satu tahun mendapatkan bahwa hasil $\mathrm{K}$ sebesar $156 \mathrm{~kg} / \mathrm{ha} /$ tahun pada baris lorong jarak $5 \mathrm{~m}$ dan $245 \mathrm{~kg} / \mathrm{ha} / \mathrm{tahun}$ pada pagar kebun $10 \mathrm{~m} \times 10 \mathrm{~m}$.

Berdasarkan data dalam Tablel 5 dapat disimpulkan bahwa perlakuan terbaik untuk mendapatkan hasil $\mathrm{P}$ dan $\mathrm{K}$ tertinggi adalah pagar kebun $10 \mathrm{~m} \times 10 \mathrm{~m}$ dengan periode pangkas 2 bulan yaitu sebesar 20,78 $\mathrm{kg} / \mathrm{ha}$ dan $89,55 \mathrm{~kg} / \mathrm{ha}$ untuk $\mathrm{P}$ dan $\mathrm{K}$ berturut-turut.

\section{KESIMPULAN}

Berdasarkan hasil percobaan rancangan baris tanam dan periode pangkas titonia pada Ultisol yang telah dibahas dapat diambil kesimpulan, bahwa rancangan baris tanam titonia dalam bentuk pagar lorong berjarak $5 \mathrm{~m}$ sama baiknya dengan bentuk pagar kebun $10 \mathrm{~m} \quad \mathrm{x} 10 \mathrm{~m}$ dalam menghasilkan biomasa (bahan organik) kering dan hasil unsur hara N, P, K, Ca dan Mg. Periode pangkas titonia yang lebih tepat dalam memperoleh biomasa dan hasil unsur hara $\mathrm{N}, \mathrm{P}, \mathrm{K}, \mathrm{Ca}$ dan $\mathrm{Mg}$ adalah tiap 2 bulan. Budidaya titonia dengan rancangan baris tanam pagar lorong jarak $5 \mathrm{~m}$ dan pagar kebun $10 \mathrm{~m} \times 10 \mathrm{~m}$ dan periode pangkas 2 bulan dapat menghasilkan sekitar 2,2 ton/ha bahan kering; $62,82 \mathrm{~kg} \mathrm{~N} / \mathrm{ha}$; $17,67 \mathrm{~kg} \mathrm{P} / \mathrm{ha} ; 81,06 \mathrm{~kg} \mathrm{~K} / \mathrm{ha} ; 13,35 \mathrm{~kg}$ $\mathrm{Ca} / \mathrm{ha}$; dan $5,47 \mathrm{~kg} \mathrm{Mg} / \mathrm{ha}$, dalam masa pemeliharaan 4 bulan.

\section{DAFTAR PUSTAKA}

Ahmad, F. 1980 Dasar-dasar ilmu tanah. Proyek Peningkatan dan Pembangunan Perguruan Tinggi Padang Universitas Andalas, 165 hal

Bibowo, A. 2005. Kombinasi pupuk buatan dan NK Tithonia dengan periode pangkas berbeda untuk tanaman jagung pada Ultisol. [Skripsi] Padang Fakultas Pertanian Universitas Andalas, 83 hal

Deswita, V. 2004. Pengaruh jarak tanam dan penambahan pupuk terhadap hasil biomassa dan kandungan unsur hara Tithonia (Tithonia diversifolia). [Skripsi] Padang Fakultas Pertanian Universitas Andalas, 77 hal 
Fidorova, Y. 2003. Substitusi N-Urea dengan N-tihonia (Tithonia diversifolia) untuk tanaman jagung pada Ultisol. [Skripsi] Padang Fakultas Pertanian Universitas Andalas, 49 hal

Gusmini. 2003. Pemanfaatan pangkasan Tithonia (Tithonia diversifolia) sebagai bahan subsitusi $\mathrm{N}$ dan $\mathrm{K}$ pupuk buatan untuk tanaman Jahe (Zingiber officinale rocs) pada Ultisol. [Tesis] Program Pasca Sarjana Unand, Padang 69 hal.

Hakim, N. 1982. Pengaruh pemberian pupuk hijau dan kapur pada tanah Podzolik Merah Kuning terhadap ketersediaan phospor pada produksi Jagung (Zea mays). [Disertasi] Doctor Fakultas Pasca Sarjana Institut Pertanian Bogor 271 hal

Hakim, N., Nyakpa, M.Y., Lubis, A.M., Nugroho, S.G., Saul, M.R., Diha, M.A., Hong,G.B., dan Bailey, H.H. 1986. Dasar-dasar ilmu tanah. Lampung Universitas 488 hal

Hakim, N., Ismal, G., Mardinus, Muchtar, H., dan Yunus. 1994. Pola pertanian terpadu di lahan kritis. Laporan Akhir Penelitian Tahun III Kerjasama Badan Litbang Pertanian DeptanPuslit Unand Padang.

Hakim, N. 2001. Kemungkinan penggunaan Tithonia (Tithonia diversivolia) sebagai bahan organik dan nitrogen. Laporan Penelitian Pusat Penelitian Pemanfaatan Iptek Nuklir (P3IN) Unand Padang.

Hakim, N. 2002 Organic matter for increasing P-Fertilizer use efficiency of maiz in Ultisols by Using 32P Tecnique. Symposium No $5917^{\text {th }}$ World Congress of Soil "Science on 14-21 August 2002, held in Bangkok

Hakim, N., Novalina, Zulfa, Mariati and Gusmini. 2003. A potential of Tihonia diversifolia for substitution of NK- Comercial for several crops in Ultisols. Paper presented at the AFA $9^{\text {th }}$ International Annual Conference on 28 - 30 Januari 2003, in Cairo.

Hakim, N. dan Agustian. 2003. Gulma Tithonia dan pemanfaatanya sebagai sumber bahan organik dan unsur hara untuk tanaman hortikultura. Laporan
Penelitian Tahun I Hibah Bersaing XI Proyek Peningkatan Penelitian Perguruan Tinggi DP3M Ditjen Dikti Unand Padang 64 hal

Hakim, N. dan Agustian. 2004. Budidaya Tithonia dan pemanfaatanya sebagai sumber bahan organik dan unsur hara untuk tanaman hortikultura di lapangan. Laporan Penelitian Tahun II Hibah Bersaing XI Proyek Peningkatan Penelitian Perguruan Tinggi DP3M Ditjen Dikti Unand Padang 64 hal

Hakim, N. dan Agustian. 2005. Budidya Tithonia dan pemanfaatannya dalam usaha tani tanaman hortikultura dan tanaman pangan secara berkelanjutan pada Ultisol. Laporan Penelitian Hibah Bersaing XI/III Perguruan Tinggi Tahun Anggaran 2005 Proyek Peningkatan Penelitian Perguruan Tinggi DP3M Ditjen Dikti Unand Padang 67 hal

Hardjowigeno, S. 2003. Ilmu Tanah. Jakarta Akademi Presindo 286 hal.

Hasnelly. 2000. Kontribusi N tanaman Kerinyuh terhadap pertumbuhan tanaman Jagung yang dirunut dengan N-15. [Tesis] Padang Program Pasca Sarjana Unand 70 hal

Husin, E. F. 1992. Perbaikan sifat kimia tanah Podzolik Sitiung melalui pemanfaatan Sesbania rostrata dan serapan Nitrogen tanaman Jagung Padang. Pusat Penelitian Universitas Andalas

Indaranada, H. K. 1989. Pengelolaan kesuburan tanah. Jakarta Bina Aksara 90 hal

Jama, BA., Palm, C.A., and Buresh, R.J. 1999. Using Tithonia and fertilizers on Maize in Western Kenya. Maseno Agroforestry Research Center Newsletter INCRAF Nairobi Kenya

Jama, BA, Palm, C.A., Buresh, R.J., Niang, A. I., Giachego, C., Nzigubeha, D. and Amalado, B. 2000. Tithonia diversifolia as a green manure for soil fertility improvement in Western Kenya: a Review Agroforestry Systems 49: 201-221 
JICA. 1982. Teori dan praktek bercocok tanam padi. Badan Penelitian dan Penyuluhan Pertanian RI, 54 hal

Ng'inja, J. O., Niang, A. I., Palm, C. A., and Lauriks, R. 1998. Traditional hedges in Western Kenya: typology, composition, distribution, uses, productivity and nenure Pilot Project. Report No 8 Regional Agroforestry Research Centre, Maseno, Kenya

Novalina. 2003. Substitusi NK pupuk buatan dengan NK Tithonia diversifolia untuk tanaman Cabai (Capsicum annum, L) pada Ultisol. [Skripsi] Padang Jurusan Tanah Fakultas Pertanian Universitas Andalas, 73 hal

Nyakpa, M.Y., Lubis, A. M., Pulung, M. A., Amran, A. G., Munawar, A., Hong, G. B. dan Hakim, N. 1988. Kesuburan tanah. Lampung Universitas Lampung

Rinsema, W. T. 1986. Pupuk dan Cara Pemupukan. Penerbit Bhratara Karya Aksara Jakarta

Rismunandar. 1986. Pengetahuan dasar tentang perabuan. Bandung Sinar Baru, 182hal

Rosmarkam, A. dan Yuwono, N.W. 2002. Ilmu kesuburan tanah. Yogyakarta Penerbit Kanisius, 224 hal

Sanchez, P. A. and Jama, B. A. 2000 Soil fertility replenishment takes off in East and Southern Africa International Symposium on Balanced Nutrient Management System for the Moist Savanna and Humid Forest Zones of Africa, held on 9 October 2000 in Benin, Africa

Sarief, E. S., 1986. Kesuburan dan pemupukan tanah. Bandung Pustaka Buana, 182 hal

Soegiman. 1982. Ilmu tanah. Terjemahan dari "The Nature and Properties of Soil" oleh H. O. Buckman dan N. C. Brady. Jakarta Bhatara Karya Aksara

Soepardi, G. 1983. Sifat dan ciri tanah. Bogor Jurusan Tanah Fakultas Pertanian Institut Pertanian, Bogor, 591 hal

Soepraptohardjo. 1978. Jenis-jenis tanah di Indonesia. Bogor BPLTP, Departemen Pertanian, 74 hal
Subagyo, Suharta dan Suwanto, A.B. 2000. Tanah-tanah pertanian di Indonesia. dalam Pusat Penelitian Tanah dan Agroklimat Sumber Daya Lahan di Indonesia dan Pengelolaannya PPTA Bogor Balitbang Pertanian Departemen Pertanian, 78 hal

Tan, K. H. 2000. Enviromental Soil Science. Second Edition New York Marcel Dekker. $224 \mathrm{p}$

Yumna, F. 2006. Efek sisa Tithonia diversifolia terhadap sifat kimia Ultisol dan hasil tanaman Cabai pada musim tanam ke dua. [Skripsi] Padang Fakultas Pertanian Universitas Andalas, 72 hal

Zamora, R. 2004. Budidaya Tithonia (Tithonia diversifolia) sebagai pupuk hijau sumber bahan organik dan unsur hara. [Skripsi] Padang Fakultas Pertanian Universitas Andalas 